\title{
Information Media Expossion of Making Decision on Early Detection for Cervical Cancer of Women Using Visual Inspection with Acetic Acid Method (VIA)
}

\author{
$1^{\text {st }}$ Atun Wigati \\ S1 Keperawatan \\ Universitas Muhammadiyah Kudus \\ Indonesia \\ atunwigati@umkudus.ac.id
}

\author{
$2^{\text {nd }}$ Hilal Ariadi, and \\ S1 Keperawatan \\ Universitas Muhammadiyah Kudus \\ Indonesia
}

\author{
$3^{\text {rd }}$ Sri Rahayu \\ S1 Keperawatan \\ Universitas Muhammadiyah Kudus \\ Indonesia
}

\begin{abstract}
Cervical cancer caused by human papilloma virus (HPV) infection ranks second with an incidence of $9.7 \%$ and a mortality rate of $9.3 \%$. Cervical cancer is one of the causes of death which is quite high in the world including in Indonesia. To prevent cervical cancer can be done with early detection using VIA method. In Kudus regency, the coverage of VIA was only $2.2 \%$. The purpose of this study is to analyze the exposure of information media to the decision making of early detection of cervical cancer in women using VIA method. This type of research uses quantitative methods with case control design. Total population of 34,184 , obtained samples consisting of cases and control groups of 43 respondents in each group, taken by purposive sampling. Data were collected using a questionnaire sheet that was distributed to all women. Data analysis techniques used the chi-square test. Statistical test results obtained $P$ value $=$ $0,000<\alpha=0.05$, it can be concluded that there is a relationship between the exposure of information media to decision making for early detection of cervical cancer usi VIA method. A score of $O R=7.255$ in $C I(2,396$ - 21,962) can mean that women who are exposed to information media well have a chance of 7.255 times to conduct early detection compared to women who are less exposed to information media.
\end{abstract}

Keywords-Media Expossion, Cervical Cancer, Women, Acetic Acid Method, VIA

\section{INTRODUCTION}

Cancer is one of the causes of death which is quite high in the world including Indonesia, can attack all levels of society from low to high economic groups, young and old, low or high educated. Globally, the incidence of cervical cancer (cervix) ranks second after breast cancer and even about 500,000 women worldwide are diagnosed with cervical cancer with an average of 231,000 people die each year[1]

Cervical cancer is one of the most common cancers affecting women throughout the world. According to the World Health Organization (WHO), this type of cancer ranks second as a cancer that often attacks women and the most occurs in developing countries. The high cases in developing countries is caused by limited access to screening and treatment so that the majority of patients who come for treatment are in critical condition and the disease is in an advanced stage.[2]

Human papilloma virus (HPV) infection has been shown to be biologically and epidemiologically responsible for causing cervical cancer. As many as 70\% of cervical cancers are caused by HPV-16 and HPV-18 types. Although HPV is an important cause, other cofactors are also needed for the onset of this cancer, such as long-term use of hormonal contraception, high parity, smoking, immunosuppression, lack of certain foods, genetic and viral factors. [3]

Cervical cancer ranks second of all cancers in women with an incidence of $9.7 \%$ and a number of deaths of $9.3 \%$ of all cancers in women in the world. Cervical cancer is a disease that occurs in the cervix which is triggered by human papilloma virus infection[4]. In Indonesia, more than 15,000 cases of cervical cancer are detected each year, and around 8,000 cases end in death. The incidence of cervical cancer in Indonesia in 2001 reached 100 per 100,000 population per year, and its spread is seen accumulating in Java and Bali. This figure is expected to continue to increase by $5 \%$ in the next 10 years if preventive measures are not taken.[2]

The low rate of early detection is one reason for the growing cervical cancer. This is based on the fact that more than $50 \%$ of women diagnosed with cancer have never had early detection before[5]

The incidence of cervical cancer can be prevented by early detection of precancerous lesions. Early detection of precancerous lesions can prevent precancerous lesions from progressing to cervical cancer if treated immediately. This is evident in developed countries that have experienced a decrease in the incidence of cervical cancer. 
For example in the United States, in the last 50 years the incidence of cervical cancer has fallen by around $70 \%$, which is possible due to a good early detection and management program. This is in line with Peirson's (2013) study, which underwent a systematic review from 1995 to 2012. The results of the study prove that early detection of precancerous lesions can reduce the incidence of cervical cancer and reduce mortality caused by cervical cancer.[6]

Five studies conducted by the Alliance for Cervical Cancer Prevention (ACCP) in South Africa, Peru, Kenya and India examined the factors that influence a woman to participate in VIA examination. The results showed that women in India and South Africa had little participation in VIA. This is influenced by lack of education, low socioeconomic status, and lack of contact with health services. The results of studies in South Africa show that women who do not access VIA early detection services, tend to be over 45 years old, poor, poorly educated, unemployed, live alone without a partner, are not familiar with other women who have participated in early detection and rarely utilize services health[7]

The high incidence of cervical cancer in Indonesia is caused by the awareness of women who are already married / having sexual relations, in conducting early detection is still low at less than $5 \%$. One of the factors that motivates women in the early detection of cervical cancer is the exposure to information media. Information can be received through direct officers in the form of counseling, from village officials through broadcasts in groups, through information media and others. In this case, a woman's behavior in conducting a VIA examination is also influenced by whether the woman has or has not received information about the VIA examination[8]

Research conducted in the working area of East Pontianak Tanjung Hulu Health Center showed that out of 107 respondents, almost all $(73.8 \%)$ were not exposed to information about cervical cancer and VIA examination and only $26.2 \%$ of respondents were exposed to information about cervical cancer and VIA examination[7]

One decisive factor public health condition is public health behavior itself. The process by which this behavior is formed is affected by several factors. One of which is social cultural factors, if these factors have been embedded and internalized in people's lives and activities exist tendency to change behaviors has been formed is difficult to done. To overcome and understand Health problems require knowledge adequate, so deep socialize health on wider community can be more directed [9]

Many factors related to the participation of mothers to participate in the IVA test include behavioral factors that are influenced by the intentions and attitudes of mothers. Based on the results of the study showed that women who behave well have greater potential to undergo IVA examination when compared with women who behave less well. The results showed that wrong perceptions (such as not having to have a check-up due to the absence of cancer symptoms, early detection of cervical cancer only for women who behave sexually that is not safe) can influence the early detection of cervical cancer detection [5]

One effort to create community behavior that is conducive to health is through health education, which is an activity to increase community knowledge, attitudes and behavior. In public health education there are educational media including films. Film is a very effective audiovisual media because the characteristics of films that can present moving images in addition to the accompanying sounds that can affect one's attitude. The results showed that the provision of health education through audiovisual media can influence attitudes towards health programs.[10]

\section{METHOD}

This research is a type of quantitative research, with an analytic observational design. Using case control design and retrospective research approaches. The population in this study were all women in Kudus Regency in 2019 as many as 34,184 people. The study was conducted in May to August 2019 consisting of case groups and control groups of 43 respondents each. The sampling technique in this study uses purposive sampling. The data collected comes from primary data and secondary data. Primary data obtained through questionnaires. Data analysis techniques using univariate analysis, bivariate analysis using chisquare test with SPSS program. The first paragraph after a heading is not indented

\section{RESULT AND DISCUSSION}

Kudus Regency is one of the regencies in Central Java province with an area of $425,165 \mathrm{~km} 2$ which is divided into 9 subdistricts, 123 villages and 9 villages. Administratively, the regency has an administrative boundary north of Jepara and Pati regencies. East of Pati regency, south of Grobogan and Pati regencies and west of Demak and Jepara Regencies. The working area of the Kudus District Health Office covers 19 puskesmas, so almost all districts have 1 puskesmas.

A. Information media exposure to women's decision making in conducting a visual inspection of acetic acid (VIA) is presented in the figure as follows: 


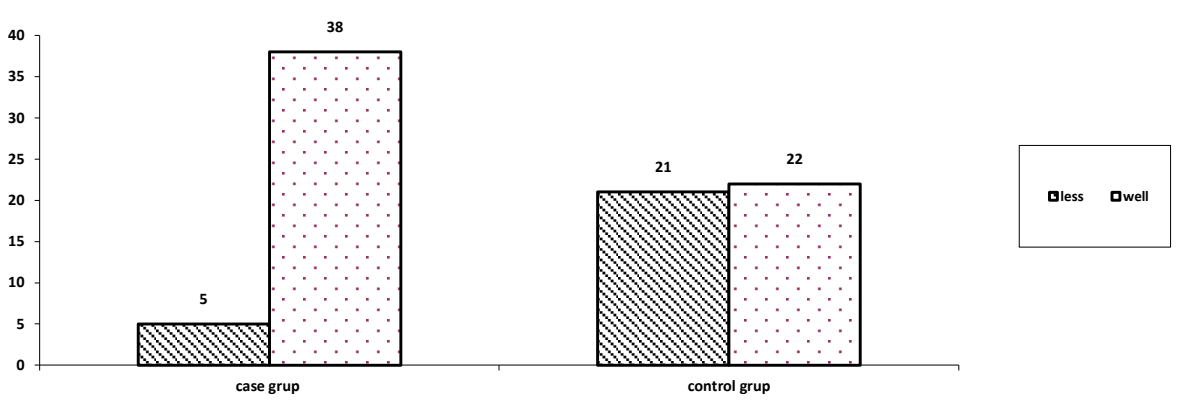

Fig. 1. Visual Inspectio of Acetic

Shows in the case group that 38 women $(88.4 \%)$ were exposed to information media well and 88 people were exposed to information media with less than 5 categories $(11.6 \%)$. In the control group most were exposed to information media well as many as 22 people (51.2), were exposed to information media less than 21 people (48.8\%)

TABLE I. ANALYSIS OF THE RELATIONSHIP

\begin{tabular}{|c|c|c|c|c|c|c|c|}
\hline \multirow[t]{3}{*}{ Information media } & \multicolumn{4}{|c|}{ Decision making } & \multirow[t]{3}{*}{ total } & \multirow[t]{3}{*}{$\chi^{2}$} & \multirow[t]{3}{*}{$\mathrm{P}$ value } \\
\hline & \multicolumn{2}{|c|}{ no via } & \multicolumn{2}{|c|}{ via } & & & \\
\hline & $\mathrm{f}$ & $\%$ & $f$ & $\%$ & & & \\
\hline less & 21 & 80,8 & 5 & 19,2 & 26 & 14,113 & 0,000 \\
\hline well & 22 & 36,7 & 38 & 63,3 & 60 & & \\
\hline total & 43 & 100 & 43 & 100 & 86 & & \\
\hline
\end{tabular}

Shows that women who were less exposed to information media did VIA examinations by $19.2 \%$, while women who were exposed to information media well tended to do more VIA examinations which were $58.9 \%$. Statistical test results obtained $\mathrm{P}$ value $=0,000<\alpha=0.05$, it can be concluded that there is a significant relationship between the exposure of information media with women's decision making in conducting VIA examinations in Kudus Regency. Obtained OR value $=7.255$ in CI $(2,396$ - 21,962), this can be interpreted that women who are exposed to information media well have a chance of 7.255 times to do VIA examination compared to women who are less exposed to information media.

Indonesia, which has a population of 240 million with $70 \%$ of its population living in rural areas, and the proportion of women is half of the population with twothirds being of reproductive age. The varied economy of the Indonesian population influences the desire to have children in a family. Exposure to mass media and education affect the desire of a woman to have children. The lack of mother's knowledge due to lack of information exposure and the low economic capacity that limits access to health services makes a mother still has many children.[11]

According to the literature, age is one of the risk factors that is considered to influence the prognosis of patients and affect the maturity of the immune system. At a young age to adulthood, immune ability will reach its peak and will gradually decrease, especially in old age. The high incidence of cervical cancer at an older age shows that there is still a lack of willingness and attention from the public to screen for cervical cancer.[12]
B. Analysis of the relationship between media information factors and women's decision making in conducting a visual inspection of acetic acid (VIA) can be seen in as follows:
The most common type of cervical cancer is squamous cell carcinoma by $73 \%$. The highest 3-5 parity is found in squamous cell carcinoma. Based on the literature the highest incidence of cervical cancer has a histological type of squamous carcinoma of $90 \%$. The type of cervical cancer histology influences the prognosis of the disease. Squamous type carcinoma has a relatively good prognosis compared to adenocarcinoma and adenosquamous carcinoma types.[13]

Information can be received through direct officers in the form of counseling, from village officials through broadcasts in groups, through information media and others. In this case, a person's behavior in conducting a VIA examination is also influenced by whether the woman has or has not received information about the VIA examination [14]

Agree with the results of a study conducted showing that of 107 respondents, almost all $(73.8 \%)$ were not exposed to information about cervical cancer and VIA examination and only $26.2 \%$ of respondents were exposed to information about cervical cancer and VIA examination [7]

The results of research which concluded that a person's exposure to health information obtained will encourage health behavior. [15]This is also supported by research conducted which states that there is a significant relationship between information exposure with WUS behavior in checking VIA with a value of 0,000 and OR 2,040 which means that WUS with good information exposure have a 2,040 times greater chance of behaving check VIA better than WUS with less information exposure[16] 
An increase in cervical carcinoma cases each year can be exacerbated by the variation in risk factors in each region. As with cancer in general, cervical cancer causes problems in the form of morbidity, mortality, financial or economic, environmental and government. Increased morbidity and mortality are influenced by how much the patient's desire to get checked out early. This is because the development of cervical cancer that takes place is very slow. Most sufferers come to the health service already in an advanced stage, so the treatment of cervical cancer gives unsatisfactory results.[17]

\section{CONCLUSIONS}

Based on the results of the study found in the case group of women who were exposed to information media well as many as 38 people $(88.4 \%)$ and in the control group of women who were exposed to information media well as many as 22 people (51.2\%). From the results of the study it can be concluded that women in the case group were well exposed to the information media more than women in the control group.

Women who are exposed to information media (television, radio, leavlets, posters) are categorized as good, meaning that exposure to information media can influence women in preventing early detection and those who are less exposed have very little chance of making early detection. counseling and through electronic information media so that cervical cancer can be detected as early as possible and can be prevented throughout the whole society of Kudus Regency.

To prevent cervical cancer, it is necessary to provide information to the public about risk factors for cervical cancer, especially for people who live far from the city center and health services. This information can be given in the form of counseling, leaflets, brochures or through other media that is easily accessed by the general public. More people are expected to do cervical cancer screening especially in high risk groups so that the incidence of cervical cancer can be reduced.

\section{REFERENCES}

[1] D. Juanda and H. Kesuma, "Pemeriksaan metode IVA ( Inspeksi Visual Asam asetat ) untuk pencegahan kanker serviks," $J$. Kedokt. dan Kesehat., vol. 2, no. 2, pp. 169-174, 2015.

[2] R. P. Y. Siwi, "Faktor-faktor yang Mempengaruhi Perilaku Pemeriksaan IVA (Inspeksi Visual Asam Asetat) dalam Deteksi Dini Kanker Serviks pada Pasangan Usia Subur," Glob. Heal. Sci., vol. 2, no. 3, pp. 220-225, 2017.

[3] F. Dwi Anggraini, "Faktor Yang Mempengaruhi Implementasi Program Deteksi Dini Kanker Serviks Melalui Pemeriksaan Iva (Inspeksi Visual Asam Asetat) Di Puskesmas Wilayah Kota Surabaya," J. Heal. Sci., vol. 8, no. 1, pp. 29-40, 2018.

[4] T. N. Adi, "Wanita dan Deteksi Dini Kanker Serviks ( Studi Korelasi antara Sikap dan Norma Subjektif dengan Intensi Wanita Dewasa dalam Pemeriksaan Deteksi Dini Kanker Serviks )," Acta diurna, vol. 7, no. 2, pp. 15-27, 2011.

[5] N. Warta, N. A. Fajar, and F. Utama, "Pengaruh Persepsi Terhadap Partisipasi Wanita Usia Subur Dalam Melakukan Screening Kanker Serviks Dengan Metode Inspeksi Visual Asam Asetat (Iva) Di Desa Talang Aur Kabupaten Ogan Ilir," J. Ilmu Kesehat. Masy., vol. 6, no. November, pp. 178-185, 2015.

[6] N. Reis, N. K. Beji, and D. Kilic, "Servikal kanser için risk faktörleri: Hastane temelli vaka-kontrol çali \{dotless $\}$ flmasi $\{$ dotless $\}$ ni $\{$ dotless $\}$ n sonuçlari $\{$ dotless $\}$," UHOD - Uluslararasi Hematol. Derg., vol. 21, no. 3, pp. 153159,2011
[7] L. Dewi and N. Sri, "Judul Hubungan Tingkat Pengetahuan Dan Sikap Wanita Usia Subur (Wus) Dengan Pemeriksaan Inspeksi Visual Asam Asetat (Iva)," Pendidik. Kesehat., vol. 1, no. 1, pp. 57-66, 2013

[8] N. Rasyid and N. Afni, "Faktor-Faktor Yang Berhubungan Dengan Perilaku Wus (Wanita Usia Subur) Tentang Deteksi Dini Kanker Leher Rahim Metode Iva (Inspeksi Visual Asam Asetat)," Promot. J. Kesehat. Masy., vol. 7, no. 1, p. 63, 2017.

[9] A. Nisak, A. Wigati, Z. Fanani, and N. Cholifah, "The Effectiveness of The Use of Cervical Cancer Prevention Guideline Book on Women Participation in Visual Inspection with Acetic acid (VIA)," vol. 15, no. IcoSIHSN, pp. 80-84, 2019.

[10] B. Budiman, Y. Mulyana Hidayat, and A. Budi Harsono, "Evaluasi Program Deteksi Dini Kanker Serviks dengan Metode See and Treat di Kabupaten Karawang," Indones. J. Obstet. Gynecol. Sci., vol. 2, no. 1, pp. 72-80, 2019.

[11] C. L. B. Lavelle, "Human papillomavirus.," Oral Surg. Oral Med. Oral Pathol. Oral Radiol. Endod., vol. 93, no. 2, pp. 125126, 2002.

[12] R. Asgary et al., "Acceptability and implementation challenges of smartphone-based training of community health nurses for visual inspection with acetic acid in Ghana: mHealth and cervical cancer screening," BMJ Open, vol. 9, no. 7, 2019.

[13] A. D. Mwaka, C. G. Orach, E. M. Were, G. Lyratzopoulos, H. Wabinga, and M. Roland, "Awareness of cervical cancer risk factors and symptoms: Cross-sectional community survey in post-conflict northern Uganda," Heal. Expect., vol. 19, no. 4, pp. 854-867, 2016.

[14] E. Masturoh, "Faktor - Faktor yang Mempengaruhi Wanita Usia Subur (WUS) dalam Melakukan Deteksi Dini Kanker Serviks Metode Inspeksi Visual Asam Asetat (IVA)," Univ. Negeri Semarang, 2016.

[15] E. Sulistiowati and A. M. Sirait, "Pengetahuan Tentang Faktor Risiko, Perilaku Dan Deteksi Dini Kanker Serviks Dengan Inspeksi Visual Asam Asetat (Iva) Pada Wanita Di Kecamatan Bogor Tengah, Kota Bogor," Bul. Penelit. Kesehat., vol. 42, no. 3, pp. 193-202, 2014.

[16] Yuliwati, "FAKTOR-FAKTOR YANG BERHUBUNGAN DENGAN KABUPATEN KEBUMEN TAHUN 2012 FAKTOR-FAKTOR YANG BERHUBUNGAN DENGAN KABUPATEN KEBUMEN TAHUN 2012,” 2012.

[17] V. H. Rasul, M. A. Cheraghi, and Z. Behboodi Moqadam, "Influencing factors on cervical cancer screening from the Kurdish women's perspective: A qualitative study.," J. Med. Life, vol. 8, no. Spec Iss 2, pp. 47-54, 2015. 